\title{
Gravity of injury and analgesia in patients who suffered traffic accidents*
}

\author{
Gravidade da lesão e analgesia em pacientes que sofreram acidentes de transporte \\ Gravedad de la lesión y analgesia en pacientes que sufrieron accidentes de tránsito
}

\author{
Ana Maria Calil ${ }^{1}$, Cibele Andrucioli de Mattos Pimenta ${ }^{2}$
}

\begin{abstract}
Objective: Identifying the frequency and gravity of injuries in patients who suffered accidents in traffic and the analgesic drugs utilized. Methods: Retrospective study, with a sample of 200 medical records of patients admitted to the emergency services of a reference hospital for trauma care. The gravity of the injuries was characterized by anatomic gravity rates and the analgesic therapy was based on the World Health Organization's Analgesic Ladder. Results: The main findings pointed to injuries in limbs, head, face and outer surface as the most frequent, and, in $85 \%$ of the cases, gravity was equal or lower than 3; As for analgesia, it was verified that 46;6\% of the patients received dipyrone and paracetamol. Among the opioids, meperidine was used in 10.4\% of the cases. Conclusion: The gravity of most injuries was equal or lower to 3, indicating injuries of light, moderate and serious gravity, located especially in four body regions; regarding analgesia, dipyrone was shown to be the most commonly-used drug and a low use of opioids was verified.
\end{abstract}

Keywords: Analgesia; Wounds and injuries; Pain

\section{RESUMO}

Objetivos: Identificar a freqüência e gravidade das lesões em acidentados de transporte e as drogas analgésicas utilizadas. Métodos: Estudo retrospectivo, com amostra de 200 prontuários de pacientes internados no pronto-socorro de um Hospital referência para o atendimento ao trauma. A gravidade das lesões foram caracterizadas por índices de gravidade anatômicos e a terapêutica analgésica com base na Escada Analgésica da Organização Mundial de Saúde. Resultados: Os principais achados apontaram as lesões em membros, cabeça, face e superfície externa como as mais freqüentes, e em $85 \%$ dos casos com gravidade menor ou igual que 3; quanto a analgesia verificou-se que $46,6 \%$ dos pacientes receberam dipirona e paracetamol, entre os opióides destacou-se a meperidina com 10,4\%. Conclusão: A maioria das lesões foram de gravidade igual ou menor a 3, indicativo de lesões de gravidade leve, moderada e séria, localizadas principalmente em quatro regiões corpóreas; quanto à analgesia, a dipirona apareceu como a droga mais utilizada e constatou-se reduzido uso de opióides.

Descritores: Analgesia; Ferimentos e lesões; Dor

\section{RESUMEN}

Objetivos: Identificar la frecuencia y gravedad de las lesiones en accidentados de tránsito y las drogas analgésicas utilizadas. Métodos: Se trata de un estudio retrospectivo, con muestra de 200 historias clínicas de pacientes internados en el servicio de emergencia de un Hospital de referencia para la atención al trauma. La gravedad de las lesiones fue caracterizada por índices de gravedad anatómicos y la terapéutica analgésica con base en la Escalera Analgésica de la Organización Mundial de la Salud. Resultados: Los principales hallazgos apuntaron las lesiones en miembros, cabeza, cara y superficie externa como las más frecuentes, y en un $85 \%$ de los casos con gravedad menor o igual a 3 ; en cuanto a la analgesia se verificó que el 46,6\% de los pacientes recibieron dipirona y paracetamol, entre los opioides se destacó la meperidina con el 10,4\%. Conclusión: La mayoría de las lesiones fueron de gravedad igual o menor a 3, indicativo de lesiones de gravedad leve, moderada y seria, localizadas principalmente en cuatro regiones corporales; en cuanto a la analgesia, la dipirona apareció como la droga más utilizada y se constató un reducido uso de opioides.

Descriptores: Analgesia; Heridas y traumatismos; Dolor

* Part of the Doctorate dissertation named: "Pain and analgesia in traffic accident victims cared for in an emergency service, defended in 2003 in the Nursing School of the Universidade de São Paulo - USP - São Paulo (SP), Brazil, by the Adult Health Program. CNPq provided a scholarship during the study.

${ }^{1}$ Doctor, Collaborating Professor at Centro Universitário São Camilo - São Paulo (SP).

${ }^{2}$ Head Professor of the Medical-Surgical Nursing Department at the Nursing School of the Universidade de São Paulo - USP - São Paulo (SP), Brazil. 


\section{INTRODUCTION}

Pain is frequently a reason to seek the emergency sector, and a large share of the services provided are consequences of traffic accidents, estimated at approximately 32,000 in the year $2001^{(1)}$. Pain is recognized as one of the main consequences of trauma, and its repercussions are identified as potentially harmful for the organism. Although frequent, little attention has been given to the trauma victim regarding pain control. This situation, of little-investigated proportions in our midst in the emergency sector, is made evident by studies from other countries ${ }^{(2)}$.

The main reasons pointed in literature as causes for shifting attention to immediate priorities, aiming to protect the patients and preserve their vital functions, transfer the issue of pain to a secondary or inexistent plane, often without justification. The organic repercussions of the intense pain process are, usually, underestimated or even ignored by physicians and nurses. Besides, there is misinformation about analgesic drug pharmacology and available techniques, and still, it is frequently alleged that early application of analgesics can mask valuable clues for the etiological diagnostic, a situation that has not been accepted in literature in years ${ }^{(2)}$.

Pain is a distressing sensory and emotional experience, associated to a real or potential tissular injury and described according to such damage. Acute pain occurs as an alert, meaning that something in the organism is not well. This type of pain is very frequent in the emergency sector, because it is related to traumatic aggravations, infections and inflammatory processes ${ }^{(3)}$.

The persistence of reaction processes in function of the permanence of acute pain results in the formation of vicious circles, with the progressive increase of organic dysfunctions and harmful effects to the trauma patient, such as hypoventilation, increased heart output, lowered peripheral blood perfusion and reflex muscular contractions. In hemorrhagic situations, nociceptive stimuli aggravate the state of shock by deteriorating the mechanical performance of the left ventricle, reducing the oxygen offer and increasing plasmatic $\operatorname{loss}^{(4)}$.

Improving tissular perfusion, minimizing cell injury and physiological changes related to hypoxia, controlling hemorrhagic situations, maintaining stable vital parameters and cervical spine stability are the priority goals of healthcare for trauma victims ${ }^{(5)}$.

Therefore, it seems clear that the adequate pain assessment, control and relief, besides the humanitarian aspect, should be a vital part of trauma care, aiming to contribute for the maintenance of basic physiological functions and avoid harmful side effects from pain permanence. Besides, knowledge of the gravity of trauma injuries may serve as a base for the creation of analgesia protocols.

In face of this reality, the authors decided to develop a study that would answer the following questions: Would there be body regions hit more frequently in traffic accidents in our midst, and which would be the gravity of such injuries? Which analgesic drugs are being used in this emergency service population?

\section{METHODS}

This is a descriptive, exploratory study with a quantitative approach.

The study was performed in a tertiary-level governmental general hospital, considered a university reference for hierarchy trauma healthcare in the Western Region of the greater São Paulo and neighboring municipalities.

In a previous study, performed in the Division of Medical Archives (DAM) of the Institution in this study, it was verified that the annual average of patients admitted for treatment due to traffic accidents was around 1,500, and, of these, approximately 640 remained in the hospital. An analysis of a sample of this population was proposed, with a desired precision of $5 \%$, expected prevalence of $50 \%$ and risk of $1 \%$, which resulted in 200 medical records to be analyzed, representing almost one third of the total population.

The selection of events considered as traffic accidents was based in the World Health Organization's criteria, expressed in the International Statistical Classification of Diseases and Health Problems (CID 10), under the alphanumerical codes V01 to V099().

With the proposed analysis, the following inclusion criteria were established: traffic accident victims coming directly from the event scene, admitted via emergency service; events classified by DAM as traffic accidents; not having progressed to death in the first 24 hours and being older than 16 years old.

The data sources included computerized lists from the Data Processing Company of the State of São Paulo, lists of patients admitted due to traffic accidents provided by DAM and medical records of patients admitted to emergency services.

After selecting the patients of interest, the author divided them into four groups, according to the external cause: automobile accidents, run-overs, motorcycle accidents and others. Out of 634 patients admitted in 2002, 250 were due to automobile accidents, 234 due to run-overs, 137 due to motorcycle accidents and 13 due to other classifications. Within each group, each medical record received a specific number, in crescent order. According to statistical orientation, 80 automobile accidents records were randomly drawn, along with 70 run-overs and 50 motorcycle victims, which altogether 
constituted the sample of 200 medical records. The request for medical records was done in groups, and, in case one of the selected records had been misplaced or lost, a "spare" other, belonging to the same group, was randomly drawn.

Data collection was started after the authorization of the Committee of Ethics for Research Project Analysis of the Hospital's Clinical Management.

A data collection sheet was prepared for each patient, and the information pertinent to the study was registered, from the moment of admission until an approximate period of 24 hours. The time of admission registered in the medical record was considered the starting point, and the time of medication in the medical record was considered the endpoint.

After analyzing 200 medical records, 17 distinct types of analgesic prescriptions were identified and regrouped in three analgesic patterns, which were the base for the analysis of this stage in the study. These are: Group I: Simple analgesic or non-hormonal anti-inflammatory (AINH); Group II: Simple analgesic+AINH+Opioid(s); Group III: Simple analgesic+Opioid(s)+Midazolan.

Group I corresponds to the first step in the WHO's Analgesic Ladder ${ }^{(7)}$, and Group II, to the second and third steps. Group III was proposed because the addition of Midazolan seemed to indicate a therapeutic objective different from Groups I and II.

In this categorization, the medication, dosage, interval and administering way were not considered. Such decision happened because a large amount of possible configurations were found, which, if not organized according to wider criteria, would make any type of statistical analysis impossible.

The anatomical Abbreviated Injury Scale (AIS) index was used to measure the seriousness of the injuries. It is presented as a manual, in which hundreds of injuries are listed according to their type, location and gravity. It's a worldwide accepted instrument for the study of the nature of injuries presented by trauma patients ${ }^{(8)}$.
The gravity of each injury contained in AIS varies from minimal gravity $=1$ to maximum gravity $=6$. By definition, injury scores equal or lower than 3 indicate light, moderate or serious gravity injuries, while those equal or higher than 4 are progressively considered grave, critical or lethal ${ }^{(8)}$.

The data were inserted in a databank for descriptive analysis processing. The results were organized in tables and presented in absolute and relative amounts.

\section{RESULTS}

Table 1 shows that 570 anatomic injuries were described in the 200 medical records of the studied patients. Each patient had an average amount of 2.8 injuries.

The patients' injuries were fundamentally concentrated in the upper limb, lower limb and pelvic waist regions (26.7\%), head/neck (20.7\%), face $(19.1 \%)$ and outer surface regions $(19.1 \%)$. These four body regions covered $86.3 \%$ of the total amount of injuries.

Regarding injury gravity, it was noticed that injuries $\mathrm{AIS}=3, \mathrm{AIS}=2$ and $\mathrm{AIS}=1$ were most frequent, respectively at $31.9 \%, 29.3 \%$ e $24.0 \%$.

Analgesic prescriptions were seen in 179 records, i.e., $89.5 \%$ of the sample. Of these, three patients that had received sedatives from the hospital itself were excluded, due to its multiple composition and low amount of cases, totaling 176 records for the analysis.

To clarify, the hospital sedative is composed by the following drugs: dipyrone, 1 gram; papaverine chlorhydrate, $30 \mathrm{mg}$; adipherine chlorhydrate, $30 \mathrm{mg}$; and homatropine methylbromide, $2 \mathrm{mg}$ (qsp- $2 \mathrm{ml}$ ). Due to its mixed composition, different from any other established standard, by not being currently used in the studied hospital and the low amount of indications found, these three patients who received said medications ended up being excluded from the study.

The distribution of the seven analgesic patterns, the regrouping of medications, medication used and the

Table 1 - Distribution of the anatomic injuries registered in the patients' medical records $(n=200)$, according to body regions and gravity scores. São Paulo, 2002.

\begin{tabular}{|c|c|c|c|c|c|c|c|c|c|c|c|c|c|c|}
\hline \multirow{3}{*}{ Body region } & \multicolumn{12}{|c|}{ Escore AIS } & \multicolumn{2}{|c|}{ Total } \\
\hline & \multicolumn{2}{|c|}{1} & \multicolumn{2}{|c|}{2} & \multicolumn{2}{|c|}{3} & \multicolumn{2}{|c|}{4} & \multicolumn{2}{|c|}{5} & \multicolumn{2}{|c|}{6} & \multirow{2}{*}{ no. } & \multirow{2}{*}{$\%$} \\
\hline & no. & $\%$ & no. & $\%$ & no. & $\%$ & no. & $\%$ & no. & $\%$ & no. & $\%$ & & \\
\hline $\begin{array}{l}\text { Upper and lower limbs and } \\
\text { pelvic waist }\end{array}$ & 12 & 2.1 & 52 & 9.1 & 78 & 13.7 & 10 & 1.8 & - & - & - & - & 152 & 26.7 \\
\hline Head/Neck & 10 & 1.8 & 18 & 3.2 & 32 & 5.6 & 52 & 9.1 & 6 & 1.0 & - & - & 118 & 20.7 \\
\hline Face & 28 & 4.9 & 62 & 10.9 & 15 & 2.6 & 4 & 0.7 & - & - & - & - & 109 & 19.1 \\
\hline Outer surface & 87 & 15.2 & 13 & 2.3 & 5 & 0.9 & 4 & 0.7 & - & - & - & - & 109 & 19.1 \\
\hline Chest & - & - & 11 & 1.9 & 28 & 4.9 & 5 & 0.9 & - & - & - & - & 44 & 7.7 \\
\hline Abdomen/pelvic contents & - & - & 11 & 1.9 & 24 & 4.2 & 2 & 0.4 & 1 & 0.2 & - & - & 38 & 6.7 \\
\hline Total & 137 & 24.0 & 167 & 29.3 & 182 & 31.9 & 77 & 13.6 & 7 & 1.2 & 0 & 0.0 & 570 & 100.0 \\
\hline
\end{tabular}


amount of identified occurrences in the medical records can be found in tables 2, 3 and 4 .

Table 2 - Distribution of patients with antialgic prescription ( $\mathrm{n}=176)$, according to prescribed medication. São Paulo, 2002

\begin{tabular}{lrr}
\hline Medication & $\mathbf{n}^{\mathbf{0}}$ & $\mathbf{\%}$ \\
\hline 1. simple analgesic & 65 & 36.9 \\
2. analgesics + AINH & 17 & 9.7 \\
3. analgesics + weak and/or strong opioid & 27 & 15.3 \\
4. analgesics + weak and/or strong opioids & 14 & 8.0 \\
5. analgesics + AINH + weak and/or strong opioid & 15 & 8.5 \\
6. analgesics + opioid + midazolan & 27 & 15.3 \\
7. analgesics + opioids + midazolan & 11 & 6.3 \\
\hline Total & $\mathbf{1 7 6}$ & $\mathbf{1 0 0 . 0}$ \\
\hline
\end{tabular}

It can be verified in Table 2 that the highest percentage lies in the utilization of simple analgesics, without any other medication $(36.9 \%)$. It is worth noting that this analgesic standard was 2.4 times more utilized than the second most frequent.

The medications were regrouped in three patterns, according to the WHO's analgesic ladder, with the distribution of patients in each group according to Table 3 .

Table 3: Distribution of patients $(n=176)$ according to groups of analgesic patterns utilized. São Paulo, 2002.

\begin{tabular}{clrr}
\hline Analgesic pattern & $\mathbf{n}^{\mathbf{0}}$ & $\mathbf{\%}$ \\
\hline I $\quad \begin{array}{l}\text { analgesic } \\
\text { analgesics + AINH } \\
\text { analgesics + opioid } \\
\text { analgesics + opioids } \\
\text { analgesics + AINH + opioid } \\
\text { analgesics + opioid + midazolan } \\
\text { analgesics + opioids + midazolan }\end{array}$ & 82 & 46.6 \\
III & 56 & 31.8 \\
\hline & Total & $\mathbf{1 7 6}$ & $\mathbf{1 0 0 . 0}$ \\
\hline
\end{tabular}

Table 4 - distribution of the prescribed analgesics ( $\mathrm{n}=353)$ according to pharmacological groups. São Paulo, 2002.

\begin{tabular}{llrr}
\hline Pharmacological Groups & & no. & \% \\
\hline \multirow{2}{*}{ Simple Analgesics } & dipyrone & 176 & 49.4 \\
& paracetamol & 16 & 4.5 \\
Non-hormonal anti- & diclofenac & 12 & 3.4 \\
inflammatory (AINH) & ketoprofen & 13 & 3.6 \\
& tenoxicam & 7 & 2.0 \\
& tramadol & 12 & 3.4 \\
& codeine & 10 & 2.8 \\
Opioids & meperidine & 37 & 10.4 \\
& morphine & 12 & 3.4 \\
Sleep inducer & fentanyl & 31 & 8.7 \\
Total & midazolan & 27 & 7.6 \\
\hline
\end{tabular}

It is observed in Table 3 that the Group I analgesic pattern was used for nearly half the patients $(46.6 \%)$.

It is important to note that the opioid fentanyl was only used in patterns 6 and 7, therefore in Group III.
The analgesics found in medical prescriptions, presented in the patterns of analgesia proposed for the analysis, were the following:

Since some patients received more than one medication, the total amount of prescribed analgesics was 353 , in the first 24 hours, for 179 patients.

In table 4 , it can be verified that dipyrone represented almost half of all pain medication prescribed (49.4\%). Among the opioids, meperidine was more often used, with $10.4 \%$.

\section{DISCUSSION}

Pain is a frequent symptom of trauma, and its occurrence and intensity may be related to the type and location of the injury. According to literature, pain in trauma is more frequently related to injuries in: lower and upper limbs, chest, head and outer surface ${ }^{(9)}$.

Countless authors report that pain in emergencies, especially in trauma patients, is under-evaluated, undertreated, with the term oligoanalgesia originating from this situation $^{(10)}$. Often intense, the pain experienced by these patients may last for hours, without any type of analgesic action being proposed ${ }^{(8-9)}$.

In this study, 570 anatomical injuries were diagnosed in the 200 patients (Table 1), with the upper limbs, lower limbs and pelvic waist being the most often affected regions, responsible for $152(26.7 \%)$ injuries, followed by the head/neck region with 118 (20.7\%) injuries.

The distribution found in this study, confirmed in literature, frequently points the upper/lower limb and pelvic waist and head/neck as the two body regions more often struck in traffic accidents, with variation for the other areas ${ }^{(11)}$.

Regarding the body region most gravely struck, head/ neck shows a rather high percentage when compared to the other regions, with 58 AIS $>4$ regions. Cranioencephalic trauma in traffic accident victims is the most commonly found isolated injury in grave and lethal cases ${ }^{(12)}$.

An important aspect related to pain control and analgesia refers to the chest region, since it is identified in recent studies as a high-risk body segment for the patient, since the permanence of pain and its harmful effects can result in respiratory failure ${ }^{(13)}$.

Lower limb, upper limb and pelvic waist injuries are worth of note, because, although they have a low lethality, they imply in long periods in the hospital, large amount of plastic and corrective surgeries, immobilization in bed, infections, pressure ulcers and, especially, pain ${ }^{(14)}$. The most common injuries were: simple and exposed fracture, dislocations, sprains, bruising, laceration and abrasion. It is also important to highlight that these injuries are reportedly very painful and have a low risk of death to the patient, not presenting, most times, warnings for 
analgesia, especially in injuries of AIS gravity lower than 3.

The WHO's analgesic ladder proposes the use, in this order, of non-hormonal analgesic anti-inflammatories, weak and strong opioids for oncological pain of increasing intensity. Aspirin, codein and morphine are the standard analgesics in this scale.

Several studies have proven the effectiveness of the program for oncological pain relief proposed by the $\mathrm{WHO}^{(3,7,15)}$. This proposal went beyond the initial recommendation for pain control in cases of cancer, and became the general guideline for pain control.

In the analysis of the 200 medical records, it was possible to identify the existence of antialgic prescription in 179 patients. At first, this information seems interesting, since it represents $89.5 \%$ of the sample. However, when the data were analyzed more closely, $65(36.9 \%)$ medical records were seen to have only dipyrone and paracetamol as the prescribed medications for antialgic treatment (Table 2).

As an example, dipyrone is highlighted, which, either isolated or grouped with other medications, was the substance most often prescribed, present 91 times "if necessary". In 60 cases, it is present as a supporting treatment, and in 31 as the only prescribed analgesic. The facts are concerning, since they suggest insufficient analgesia for the gravity and frequency of the injuries. The isolated use of analgesics (dipyrone or paracetamol), as the only active principle for pain relief in the emergency services induces the researchers to the question: Are the physicians in the emergency sector being too economic with analgesia? (16).

Dipyrone is probably the most commonly used analgesic in the past decades, because besides analgesic action, it also has antithermic action. It is a traditional, very often used medication, whose effect is not questioned. However, its isolated indication for moderate and intense post-trauma pain may be insufficient ${ }^{(17)}$.

The questioning seems opportune, since the reports in literature are unanimous when pointing to the utilization of strong opioids (meperidine and morphine) as the ideal and necessary drugs for treating intense pain, and weak opioids (codeine and tramadol) for moderate pain ${ }^{(7,14)}$.

Opioids are the most potent analgesics. Therefore, they provide pain relief, well-being to the patient and it is believed that, in the near future, they will be more widely used because of their beneficial effects. Nowadays, the use of opioids is restricted to physicians specialized in pain, neurologists and anesthesiologists ${ }^{(16)}$. Due to their potency, they are indicated for moderate and intense pain and treatment of acute or chronic situations ${ }^{(3)}$.

The reduced use of strong opioids in the emergency sector, particularly morphine $(3.4 \%)$ and meperidine $(10.4 \%)$ (Table 4$)$ may be related to the stigma of dependence associated to such drugs, a factor that is not related to the use in acute pain situations in the emergency sector, and also to the lack of knowledge and fear of the healthcare professionals in using these medications ${ }^{(18)}$.

In a study involving 1000 patients with acute or chronic pain and using opioids, adverse reactions such as nausea, vomiting and constipation were identified in only $2 \%$ of the population, with such effects being controlled with supporting therapies and appropriate diet. Respiratory insufficiency was identified in only one patient ${ }^{(19)}$.

One of the reasons for the low importance conferred to analgesia in the emergency sector is the situation of urgency and emergency, where the resuscitation and stabilization aspects are prioritary. The priorities to politrauma patients are unquestionable, but the questions about other aspects favoring assistance quality are fundamental, such as inclusion of pain assessment and control, use of objective instruments for assessing pain intensity, utilization of protocols and the benefits that come from these practices ${ }^{(20)}$.

The observation of the medical records allowed the identification of some intriguing and concerning aspects, such as the lack of standards regarding analgesia. For patients with the same type of injury, for example, isolated exposed fractures, hemodynamically stable patients, and score 15 as per the Glasgow coma scale, four distinct prescriptions were found: no analgesic prescription; exclusive use of dipyrone; exclusive use of non-hormonal anti-inflammatory; use of opioid (morphine).

Regarding this situation, it is worth wondering: Would the patients have been evaluated objectively regarding the pain phenomenon? Would they have presented such disparate intensity pain symptoms? Would the doctors have followed some analgesia protocol?

In a prospective study performed by the authors in the same hospital where this research was done, some of the questions pointed above could be answered. These are: no objective instrument was used in the emergency service for the measurement of pain to graduate or score the pain intensity; a significant number of patients $(85 \%)$ presented medium or strong intensity pain after the trauma, which would already indicate the use of opioids according to the WHO; pain was characterized as continuous, and present immediately after the traumatic event. No analgesia protocol was followed by the healthcare teams, and $48 \%$ of the patients remained without analgesic treatment after 3 hours of admission in the service. It is important to note that only hemodynamically stable patients with a score of 15 in the Glasgow coma scale were analyzed ${ }^{(9)}$.

A fundamental aspect to be highlighted refers to the attitude of the medical and nursing professionals of the sector, when they state that analgesia for the trauma patient is not a very highly regarded aspect of the emergency 
service, and this attitude needs to be changed as soon as possible.

This wide-ranging panorama, from the hemodynamic and emotional viewpoint for the patient, still not well investigated in our midst, deserves space in future investigations that can fill gaps and improve this discussion.

\section{CONCLUSION}

The body regions most often hit in traffic accident

\section{REFERENCES}

1. Secretaria de Estado da Saúde de São Paulo. Coordenadoria de Controle de Doenças. Centro de Vigilância Epidemiológica "Prof. Alexandre Vranjac". Grupo Técnico de Prevenção de Acidentes e Violências. O impacto dos acidentes e violências nos gastos da saúde. Rev Saude Publica = J Public Health. 2006; 40(3):553-6

2. Kelly AM. A process approach to improving pain management in the emergency department: development and evaluation.J Accid Emerg Med. 2000; 17(3): 185-7. Comment in: Emerg Med J. 2001;18(4):321-2.

3. International Association for Study of Pain (IASP). Consensus development conference statement: the integrated approach to the management of pain. J Accid Emerg Med 1994; 6(3): (document number-491-292).

4. Kanner R. Segredos em clínica de dor. Porto Alegre: Artes Médicas; 1998

5. American College of Surgeons - ACS. Committee on Trauma. Suporte Avançado de Vida no Trauma - SAVT: Programa para Médicos. Trad. do Programa ATLS. São Paulo; 2004

6. Organização Mundial da Saúde. Classificação estatística internacional de doenças e problemas relacionados à saúde: CID 10. Manual de instrução, trad. do Centro Colaborador da OMS para Classificação de Doenças em Português. 10a ed. São Paulo: EDUSP; 1994

7. Organização Mundial da Saude. Alivio del dolor em el cancer. Ginebr: OMS; 1987.

8. Association for the Advancement of Automotive Medicine. Committee on Injury Scaling. The Abbreviated Injury Scale 1990. Revision (AIS-90). Update 98. Des Plaines, Il.: Association for the Advancement of Automotive Medicine; 1998.

9. Calil AM. Dor e analgesia em vítimas de acidentes de transporte atendidas em pronto-socorro. [tese ]. São Paulo: Escola de Enfermagem da Universidade de São Paulo; 2003.

10. Bell TL, Mitchiner JC, Frederiksen SM, McCormick J. Patient victims were the lower and upper limbs, head/neck, face and outer surface. Regarding the injury gravity, the head/ neck body segment was the one most often struck. The analgesic drug most often used was dipyrone, in 46.6\% of the cases. The importance of new investigations in this area in our country is highlighted, considering the high number of external causes, the improvement of healthcare quality related to pain relief, the need of creating analgesia protocols and objectivity in pain assessment in the emergency services.

preferences regarding pain medication in the ED. Am J Emerg Med. 2000; 18(4): 376-80.

11. Malvestio MAA. Predeterminantes de sobrevivência em vítimas de acidentes de trânsito submetidas a atendimento pré-hospitalar de suporte avançado à vida [tese ]. São Paulo: Escola de Enfermagem da Universidade de São Paulo; 2005.

12. Gennarelli TA, Champion HR, Copes WS, Sacco WJ. Comparison of mortality, morbidity, and severity of 59,713 head injured patients with 114,447 patients with extracranial injuries. J Trauma. 1994; 37(6): 962-8.

13. Boutros F, Redelmeier DA. Effects of trauma cases on the care of patients who have chest pain in an emergency department. J Trauma. 2000; 48(4): 649-53.

14. Ward KR, Yealy DM. Systemic analgesia and sedation in managing orthopedic emergencies. Emerg Med Clin North Am. 2000; 18(1): 141-66, vi.

15. Slaughter A, Pasero C, Manworren R. Unacceptable pain levels. Am J Nurs. 2002; 102(5): 75,77.

16. Lewis LM, Lasater LC, Brooks CB. Are emergency physicians too stingy with analgesics? South Med J. 1994; 87(1):7-9.

17. Wannamacher L, Ferreira MBC. Analgésicos não opióides. In: Fuchs FD, Wannamacher L. Farmacologia clínica: fundamentos da terapêutica racional. Rio de Janeiro: Guanabara Koogan; 1998. p. 166-71.

18. Alpen MA, Morse C. Managing the pain of traumatic injury. Crit Care Nurs Clin North Am. 2001; 13(2): 243-57.

19. Brewer BJ, Golden GT, Hitch DC, Rudolf LE, Wangensteen SL. Abdominal pain. An analysis of 1,000 consecutive cases in a University Hospital emergency room. Am J Surg. 1986; 131(2): 219-23.

20. Calil AM, Pimenta CAM. Alívio da dor no trauma: prioridade a ser discutida pela equipe de saúde. Dor em Foco 2000; $3(1): 2-4$. 